Poster Section

\title{
Effect of two homeopathic remedies at different degrees of dilutions on the wound closure of 3T3 fibroblasts in in vitro scratch assay
}

\author{
Katarina Hostanska ${ }^{1}$, Matthias Rostock ${ }^{1}$, \\ Stephan Baumgartner², Reinhard Saller ${ }^{1}$
}

\author{
${ }^{1}$ University Hospital Zürich, Institute for Complementary Medicine, Zürich, Switzerland \\ 2 Institute of Complementary Medicine KIKOM, University of Bern, Switzerland
}

\begin{abstract}
Background: Since ancient times, preparations from traditional medicinal plants e.g. Arnica montana, Calendula officinalis or Hypericum perforatum have been used for different wound healing purposes. The aim of this study was to investigate the efficacy of the commercial low dilution homeopathic remedy Similasan ${ }^{\circledR}$ Arnica plus Spray, a preparation of Arnica montana 4x, Calendula officinalis 4x, Hypericum perforatum $4 \mathrm{x}$ and Symphytum officinale 6x (0712-2) and medium diluted SIM WuS (Petroleum 15x, Arnica montana 15x, Calcium fluoratum 12x, Calendula officinalis 12x, Hepar sulfuris 12x and Mercurius solubilis 15x; 1101-4), on the wound healing in cultured NIH 3T3 fibroblasts. Both remedies were from Similasan AG (Jonen, Switzerland) and prepared according the German Homoeopathic Pharmacopoeia (GHP) following descriptions 4a for arnica, 3a for marigold and St. John's wort, 2a for comfrey, 5a for petroleum, and 6 for calcium fluoride, hepar sulfuris and mercurius solubilis.
\end{abstract}

Materials and Methods: Cell proliferation, migration and wound closure promoting effect of the preparations (0712-2, 1101-4) and their succussed solvents (0712-1, 1101-3) were investigated on mouse NIH 3T3 fibroblasts. Cell viability was determined by WST-1 assay, cell growth using BrdU uptake, cell migration

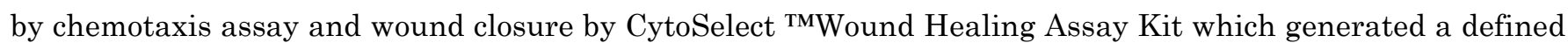
wound area. All assays were performed in three independent controlled experiments. In some experiments diluted unsuccussed alcohol (0712-3) was also investigated.

Results: Preparations (0712-1), (0712-2), (0712-3), (1101-3) and (1101-4) were investigated at decimal dilution steps from $1 \mathrm{x}$ to $4 \mathrm{x}$. Cell viabilty was not affected by any of the substances and (0712-1) and (0712-2) showed no stimulating effect on cell proliferation. Preparation (0712-2) exerted a stimulating effect on fibroblast migration $(31.7 \%)$ vs $15 \%$ with succussed solvent $(0712-1)$ at $1: 100$ dilutions $(p<0.001)$. Unsuccussed solvent (0712-3) had no influence on cell migration (6.3\%; $>>0.05)$. Positive control $2 \mathrm{ng} / \mathrm{ml}$ EGF increased migratory activity of cells by $49.8 \%$. Preparation (0712-2) at a dilution of 1:100 promoted in vitro wound closure by $59.5 \%$ and differed significantly $(\mathrm{p}<0.001)$ from succussed solvent $(0712-1)$, which caused $22.1 \%$ wound closure. Medium diluted remedy (1101-4) exerted accelerating effect on wound closure after $14 \mathrm{~h}$ of treatment. Wounded area was closed by $20 \%$ with (1101-4) and 13\% by (1101-3) compared to untreated control. Succussed solvent (1101-3) caused about 23\% and the remedy (1101-4) about 30\% wound closure after 
24h. Remedy (1101-4) and succussed solvent (1101-3) modestly stimulated cell growth at dilutions 1:100 and 1:1000 by about $25 \%$ and $15 \%$, respectively. No statistically significant differences between preparations 1101-3 and 1101-4 could be detected.

Conclusions: Our results demonstrate that the Similasan ${ }^{\circledR}$ Arnica plus low dilution homeopathic remedy exerted wound healing potential, which is a result of increased ability of fibroblasts to migrate without affecting cell proliferation. Medium diluted preparation SIM WuS exerted stimulating effect on the wound closure accompanied by a cell proliferating effect.

Used in vitro wound closure test was sensitive enough for low dilutions preparation, however for medium diluted preparation despite of a trend, no significant differences could be detected.

Key words: wound healing, 3T3 fibroblasts, homeopathic remedy, arnica, calendula

\section{(c) EY-NC-ND Licensed to GIRI}

Support: Thi work was partly funded by the Research Department of Similasan Ag (Jonen, Switzerland). Interpretation of results was the prerogative of the authors. Publication of results was occurs regardless of the outcome.

Conflict of interest: The authors declare that they have no competing interests.

Received: 01 June 2012; Revised: 08 August 2012; Published: 30 September 2012.

Correspondence author: Katarina Hostanska, katarina.hostansky@usz.ch

How to cite this article: Hostanska K, Rostock M, Baumgartner S, Saller R. Effect of two homeopathic remedies at different degrees of dilutions on the wound closure of 3T3 fibroblasts in in vitro scratch assay. Int J High Dilution Res [online]. 2012 [cited YYYY Month dd]; 11(40):164-165. Proceedings of the XXVI GIRI Symposium; 2012 Sep 20-22; Florence (Italy). GIRI; 2012; Available from: http://www.feg.unesp.br/ ojs/index.php/ijhdr/article/view/595/582 